http://dx.doi.org/10.4314/gjl.v6i2.7

\title{
DISCOURSE OF DENUNCIATION: A CRITICAL READING OF CHINUA ACHEBE'S MAN OF THE PEOPLE
}

\author{
Mawuloe Koffi Kodah
}

\begin{abstract}
Achebe's narrative text, A Man of The People (1966), is a political satire in which he exposes the intricacies of democratic politics in a Nigerian setting. At the heart of this narrative is a clear denunciation of a bastardized political system in a perverse socio-cultural and economic environment similar to what pertains in Ayi Kwei Armah's The Beautyful Ones Are Not Yet Born (1968), Ahmadou Kourouma's The Suns of Independence (1970) and Amu Djoleto's Money Galore (1975), among many others. Despite the fact that $A$ Man of The people was published in 1966, its central theme, that is politics, corruption and underdevelopment in Africa, is still relevant to contemporary sociocultural, economic and political context in Africa. No doubt the novel is classified among African classics in literary studies, as it is one of the narrative texts studied in universities across Africa and beyond. This study seeks to critically examine the nature of linguistic tools and stylistic detours that define the satiric outlooks of this narrative text of Achebe as a denunciative discourse and its impact on the effective transmission of the message of socio-cultural and attitudinal transformation for sustainable socio-economic and political development. Considering the nature of literature as a social discourse (Fowler 1981), the study will be posited in the theoretical framework of critical discourse analysis CDA (van Dijk, 1993b). Critical discourse analysis is a type of discourse analytical research that primarily studies the way social power abuse, dominance, and inequalities are enacted, reproduced, and resisted by text and talk in the social and political context (van Dijk, 2001).
\end{abstract}

Keywords: Bastardization, corruption, denunciation, discourse, politics, trivialization 


\subsection{Introduction}

Achebe's narrative text, A Man of The people, is a socio-political satire in which socio-political and economic actors in a fictional Nigerian setting are lampooned for an unprecedented level of corruption and derailment that characterize the country's sociopolitical life and are tearing it apart, following her independence from British colonial exploitation.

Discourse is severally defined as: serious speech or piece of writing; a serious and lengthy speech or piece of writing about a topic; serious conversation; serious discussion about something between people or groups. In linguistics, it stands for language, especially the type of language used in a particular context or subject. It also looks at discourse as a major unit of language, especially spoken language that is longer than the sentence. Foucault (1972: 29) defines discourse as "Systems of thoughts composed of ideas, attitudes, and courses of action, beliefs and practices that systematically construct the subject and the worlds of which they speak." This definition is perhaps the most pertinent of all, in that it encompasses all the dimensions of the subject matter of this paper. It therefore provides the conceptual tools for the study. In denouncing this state of affairs, Achebe's narrative discourse is predominantly deflationary and condemnatory of the principal political actors. In the succeeding paragraphs, I will critically examine Achebe's use of language in the service of sociopolitical criticism.

The term "denunciation" refers to "public condemnation: a public accusation or condemnation of something or somebody. It is an open or subtle rejection of what is considered an affront to public morality, legality and sociocultural, economic and political integrity.

Denunciations are spontaneous communications from individual citizens to the state (or to another authority such as the church) containing accusations of wrongdoing by other citizens or officials and implicitly or explicitly calling for punishment (Fitzpatrick and Gellately 1997). A close look at this definition shows that it highlights only the negative side of the concept. Thus, as Gellately (2001: 16-17) notes, "that definition is useful, but it tends to emphasize the negative or repressive side of denunciations." However, he points out that "in fact, denunciations are often used for 'positive' or instrumental purposes." Gellately further intimates that:

Denunciations, by their very nature, lend themselves to being used not only by good intentioned citizens, but as much and more by the unscrupulous ones. That is why in most societies, the very concept of denunciation carries pejorative or negative meanings and implications" (2001: 17). 
Indeed, this appears to be the case with its use in Achebe's discourse in A Man of the People. The two scenarios are manifest in this narrative discourse and become a major source of conflict which contributes tremendously to the development of the plot and storyline in the text.

The prime nature of the denunciation which marks Achebe's discourse in A Man of the People is satirical. A satire is an artistic form in which individual or human vices, abuses, or shortcomings are criticized through the use of certain characteristics or methods. It is usually found in dramas and narrative texts, and in modern media forms such as cartoons, films, and other visual arts. In other words, a satire is a form of irony that ridicules the faults of humanity, but always in the interests of society; it is both kind and cruel.

As a literary technique employed by writers, satire helps to expose and criticize the foolishness and corruption of an individual or a society by using humour, irony, exaggeration or ridicule. It intends to improve humanity by criticizing its follies and foibles. Achebe in a satirical style uses fictional characters, which stand for real people, to expose and condemn their corruption and contributions to social perversion.

There are three main types of satire: Horatian satire, Juvenalian satire and Menippean satire. The first two of these are named after ancient Roman satirists Horace (first century BCE) and Juvenal (late first century BCE to early second century $\mathrm{AD}$ ) - while the third is named after the ancient Greek parodist Menippus (third century $\mathrm{BCE})$.

Horatian satire playfully mocks the societal norms of its day, and the satire named after Horace is clever, yet gentle. Rather than attacking evils, Horatian satire ridicules universal human folly so that the reader might identify with what is being critiqued and laugh at himself / herself as well as at society.

Juvenalian satire, unlike Horatian satire, attacks public officials and governmental organizations through aggressive invective and overt abuses. It regards their opinions not just as wrong, but instead as evil. Juvenalian satire thus is more contemptuous and abrasive, and uses strong irony and sarcasm. Polarized political satire is often of this nature, and aims to provoke change. Juvenalian satire is not often as humorous.

Menippean satire, on its part, criticizes mental attitudes rather than societal norms or specific individuals. This type of satire often ridicules single-minded people, such as bigots, misers, braggarts, and so on. A Man of the People, as a satirical text, is characterized by irony, paradox, antithesis, colloquialism, anti-climax, violence, obscenity, vividness and exaggeration.

Considering the nature of the subject matter of his discourse and the obvious fixation on his main character, Chief the Honourable Nanga, Achebe uses a combined impulse of both Juvenalian and Menippean satirical denunciations which enables him 
to employ a more abrasive tone in criticizing social 'evils' or socio-cultural, economic and political corruption in the text through disparaging, offensive and brutal ridicule to reproof the prevailing political bigotry and socio-cultural and economic perversion in A Man of the People.

The narrator sounds virtually pessimistic, using sharp sarcasm to criticize these social issues. Through Juvenalian and Menippean types of satire, Achebe's denunciation focuses on morals and social change rather than mere humour. Both are characteristically geared towards political satire meant to bring about positive social changes and reforms. This is indeed the fundamental characteristic of $A$ Man of the People as it reflects the prime characteristics of a satire in its harmonization of irony, paradox, antithesis, colloquialism, anti-climax, violence, obscenity, vividness and exaggeration to effectively accentuate the denunciative nature of the text.

In an attempt to establish that Achebe's narrative text is a discourse of satirical denunciation, the study explores the following research questions: What are the choicest satirical linguistic tools used by Achebe in A Man of the People? What is the nature of stylistic detours of satirical denunciation in A Man of the People? What is the significance of the combined use of these linguistic tools and stylistic detours to attitudinal and behavioural transformation for better democratic governance?

\subsection{The choicest satirical linguistic tools in use in A Man of the People}

A critical reading of A Man of the People reveals Achebe's predominant use of two main types of linguistic tools in this narrative. These are satirical denunciation lexical items and satirical denunciation syntactic structures.

The satirical denunciation lexical items are characterized by Achebe's choice of appreciative and depreciative modifiers in the text. The satirical denunciation syntactic structure, on its part, is marked by the use of compound sentences in the active voice, dialogue, direct speeches interspersed with infusions of Pidgin English, invectives and first person singular narrative.

A modifier is a word, phrase, or clause which functions as an adjective or an adverb to describe a word or make its meaning more specific. Appreciative modifiers are the types of adjectives, adverb phrases or clauses which put positive qualitative or quantitative values on a person, an animal, an object or a place. On the other hand, depreciative modifiers are the opposites of appreciative modifiers. They confer negative qualitative or quantitative values on persons, animals, objects or places. Both types of modifiers are judgemental and betray the subjectivity and biases of the narrator and any other characters using them in the text. These are further reinforced by 
purposeful use of action verbs to enhance the theatrical scenes in the text for effective satirical aesthetic impact.

In the following lines, Achebe's narrator uses appreciative modifiers to set in motion the attempt to expose his main character, Nanga, to public ridicule and reproof. He affirms:

No one can deny that Chief the Honourable M.A. Nanga, MP, was the most approachable politician in the country. Whenever you asked in the city or in his home village, Anata, they would tell you he was a man of the people. (2001: 1).

The italicized modifiers in the above lines from the narrative are appreciative in nature, in that they appear to be extolling the virtues of Mr Nanga. These modifiers though appreciative in nature, are used ironically to expose Nanga as a ludicrous character who epitomizes unscrupulous politicians and public figures in a perverted multiparty democratic setting. Besides, the narrator decries the gullibility of the inhabitants of Anata, Chief Nanga's home village as they congregate to give him a befitting welcome home as a man of the people. He intimates "[...] in those highly political times the villagers moved in and virtually took over. The Assembly Hall must have carried well over thrice its capacity. Many villagers sat on the floor, right up to the foot of the dais" (2001: 1). In this instance, the narrator uses intensifiers to hype his revulsion over the behaviour of these villagers. The hyperbolical stance of the narrator's denunciation of the gullible villagers of Anata is carried further as he highlights their behaviours and apparel. He says: "Five or six dancing groups were performing at different points in the compound. The popular 'Ego Women's Party' wore a new uniform of expensive Accra cloth. (2001: 1). Whereas the cardinal numeral adjective 'five' and 'six' in the noun phrase "Five or six dancing groups" exposes the narrator's abhorrence of the villagers" enterprising political patronage as demonstrated in the multitude that gathered on this occasion of the visit of Chief the Honourable M.A. Nanga, MP, the mention of 'new uniform of expensive Accra cloth' worn by members of the 'Ego Women Party' is a denunciation of the ostentation and extravagance associated with such 'highly political times'. The narrator further expresses his aversion for political patronage linked to personality cult and praise-singing as he focuses his narrative lenses on one of the women singers in the following lines:

In spite of the din you could still hear as clear as a bird the highpowered voice of their soloist, whom they admiringly nicknamed 'Grammar-phone'. Personally I don't care too much for our women's dancing but you just had to listen whenever Grammar- 
phone sang. She was now praising Micah's handsomeness, which she likened to the perfect, sculpted beauty of a carved eagle, and his popularity which would be the envy of the proverbial traveller-todistant-places who must not cultivate enmity on his route. (2001: 1)

The italicized modifiers in the above lines are appreciative of Micah's physical appearances. "Micah was of course Chief the Honourable M.A. Nanga, MP" (2001: 1). However, the understatement of the narrator in the sentence "Personally I don't care too much for our women's dancing but you just had to listen whenever Grammar-phone sang" reveals his disapproval of such disdainful and debasing acts like political praisesinging and dancing in honour of a dishonourable and despicable character like Chief the Honourable M.A. Nanga, MP. This is also a denunciation of moral corruption which propels the people to behave the way they do so as to survive in the perverted setting of the narrative.

The 'Ego Women's Party' is not the only group involved in the ignominious act of political praise-singing. The hunters' guild of Anata, whose "members' arrival in full regalia caused a great stir", is also cited for reproof. The italicized prepositional phrase 'in full regalia' highlights the seriousness the hunters' guild attaches to the visit of Chief Nanga. The narrator points out a clear dichotomy between this visit and the unusual apparel of members of the hunters' guild. "These people never came out except at the funeral of one their numbers, or during some very special and outstanding event. I could not remember when I last saw them. They wield their loaded guns as though they were plaything" (pp. 1-2). Ironically, they are also out on this socio-culturally insignificant event such as the visit of a corrupt and disdainful political figure such as Chief Nanga. This is not "a funeral of one of their numbers" neither is it "some very special and outstanding event." The narrator hereby brings to the fore the bastardization of the people's norms and practices resulting from political patronage and moral corruption. He also alludes to economic and financial challenges which are ironically holding the people in check as they pretend to be actively demonstrating their reverence for the visiting Minister, Chief the Honourable M.A. Nanga, MP. He humorously states:

Occasionally a hunter would take aim at a distant palm branch and break its mid-rib. The crowd applauded. But there were very few of such shots. Most of the hunters reserved their precious powder to greet the Minister's arrival - the price of gunpowder like everything else having doubled again and again in four years since this government took control. (2001: 2) 
The parenthetical comment clause in italics in the above quotation evokes the worrying economic status of the people involved in this wasteful dissipation of their scarce resources. This is also a kind of denunciation of governmental failure to check inflationary trends in the country's economy. Chief Nanga, a member of parliament from the ruling party, is jointly denounced and rejected together with the political elite that make this government.

The harmonious combination of these linguistic tools by the narrator and the various characters in the narrative brings out the poignant and condescending nature of the subject matter of the narrative which is the destructive nature of socio-cultural, economic and political perversion in governance and nation building. How does the harmonious combination of these linguistic tools resonate with the corresponding stylistic detours in the production of the satirical denunciation discourse in the narrative? The study seeks to answer this question through the examination of the nature of the stylistic detours of satirical denunciation in the text.

\subsection{Nature of the stylistic detours of satirical denunciation in A Man of the People}

Many are the stylistic detours of satirical denunciation in the narrative. Key among these are: first person narration, characterization, conflict, dialogue, flashback and invective. This part of the study focuses on the use of these stylistic detours in the concretization of satirical denunciation in the narrative as a social discourse.

\subsection{First-person singular narration}

A Man of the People is a first person singular narrative. The narrator, Odili Kamalu is at the same time an active character in the story he relates. The text is entirely his story and how he sees, lives with and relates to other characters in Achebe's textual universe in A Man of the People. He therefore moderates the story from a subjective perspective, in that, readers see, hear and know only what he wants and likes to reveal to them. He tells his own story intertwined with those of others. The very first indices of his overbearing presence and moderation of the narrative are found in the following words: "I have to admit from the outset or else the story I'm going to tell will make no sense." The first person singular subject personal pronoun 'I' as used in 'I have ... and I'm going to...' stands for the narrator. He affirms his identity as the owner of the story he is about telling. This overbearing presence of the first-person narrator is a subtle intrusion of the voice of the author in the narrative. 


\subsection{Characterisation}

Characterization is the means by which writers present and reveal a character, a fictional individual to whom roles are assigned in a literary text. Achebe reveals his characters in A Man of the People through their speech, dress, manner, and actions. This is done by the first person singular narrator who is the sole presenter of characters and events that make the story in the text.

The narrator appears to have a fixation on Mr Nanga who happens to be the main character of the story. The narrator, an apparently idealistic young university graduate, is to some extent, a foil of the main character, a pragmatic and opportunistic politician. Indeed, the title of the narrative is a designation for the main character. This is revealed to the reader in the very first paragraph of the narrative. He states:

\section{No one can deny that Chief Honourable M.A. Nanga, MP, was the most approachable politician in the country. Whether you asked in the city or in his home village, Anata, they would tell you he was a man of the people. $(2001: 1)$}

The accumulation of nominal titles 'Chief Honourable M.A. ... MP' for Mr Nanga brings out the narrator's aversion for the character as a self-conceited megalomaniac. The name 'Nanga' is ironically magnified through the nominal phrases used as descriptive modifiers. This is to denounce $\mathrm{Mr}$ Nanga as a selfish, greedy and unscrupulous public figure and politician. The narrator's hidden ironical intents get unveiled in the subsequent paragraphs as he decries the most elaborate preparations, pomp and pageantry put in place by the people of Anata to feast Chief Nanga "due to address the staff and students of Anata Grammar School [...] (2001: 1). Progressively, Chief the Honourable M.A. Nanga, MP's infamous popularity gets revealed to the reader.

Chief Nanga is obviously an epitome of greedy and unprincipled politicians and public figures who adorn themselves with accumulated empty titles to gratify their egoistic instincts. Hollow as they are, these titles are tools of ambivalent manipulations between them and their equally corrupt and contemptible supporters and followers. Whereas politicians and public figures feel elated and highly esteemed as those titles are poured on them in public, their followers on their part use these titles to seduce and win the favours of these unsuspecting politicians and public figures whose folly is being exposed in this style by the narrator. Come to think of it, it is not out of real reverence that these titles are lavished on such people, since most of them do not live according to the virtues imbedded in those titles. They are actually a distrusted and scornful bunch of people in the eyes and minds of the people. They are mere stooges in the eyes of the 
people who manipulate them to satisfy their socio-economic needs while pretending to love and revere them in public.

Chief the Honourable M.A. Nanga, MP's insatiable taste for popularity and fame is further rebuffed in the narrative when the narrator makes him to proudly announce his trip to the USA to be awarded a doctorate degree in the following words: "They are going to give me doctorate degree... Doctor of Laws, LL D" (2001: 16). Ironically, Chief the Honourable M.A. Nanga, MP has throughout his political life demonstrated an incurable aversion for intellectuals and university-trained and professional men, whose degrees and titles he holds in abject contempt. Yet, here is Chief the Honourable M. A. Nanga, MP, elated to be given a university degree title which obviously will boost his egocentric character a step further.

The narrator in Achebe's A Man of the People is endowed with a strong descriptive prowess through which he forcefully caricatures characters and situations in a lasting pictorial manner. He blends the description with denunciative hyperbole, a kind of deliberate exaggeration through which his heightened aversion for the sociopolitical ills and actors in the text is affirmed. Hyperbolical denunciation is indeed a driving force in the narrative, considering the level of the narrator's disappointment and anger, as he appears rather as a socio-political misfit in a bastardized society in the wake of political independence, as a result of his incorruptible stands. His idealistic persuasions are in conflict with the pragmatic survival orientations of Chief the Honourable M. A. Nanga, MP and most of the other characters in the narrative. This conflict contributes immensely to the dynamism of the plot and propels the narrative. Out of this artistic ingenuity come metaphorical and ironical denunciations which reinforce the aesthetic stance of the narrative and the impact of the narrator's denunciative posturing. Whereas the metaphoric denunciation is found in the use of implicit, subtle comparisons through which characters and situations assume bestial characteristics and concrete natures in order to effectively attract the displeasure and scorn of readers, Ironical denunciation results from the narrator's juxtaposition of contradictory viewpoints and incongruities in the speeches and actions of the principal characters so as to expose the hypocrisy and double-stand which are the hallmarks of the perverse socio-political life in the text. What then is the significance of the combined use of these linguistic tools and stylistic detours to attitudinal and behavioural transformation for better democratic governance and sustainable human development in Achebe's A Man of the People? 


\subsection{Significance of the combined use of linguistic tools and stylistic detours to attitudinal and behavioural transformation for better democratic governance}

Achebe's discourse in A Man of the People is premised on the satirical denunciation of socio-economic and political corruption in various forms and at varying degrees in a newly independent fictional Nigerian setting. The significance of the combined use of the choicest satirical linguistic tools and stylistic detours examined in the preceding paragraphs is found in the manifestation of satirical denunciation of the above ills in four main categories in the discourse. These are: rejection of socioeconomic and political perversion, condemnation of selfishness and greed, denunciation of unhealthy social-political and economic stratification; rising 'intellecto-phobia', and rebuff of media corruption and terrorism.

The narrative denounces the media and media practitioners as incredibly corrupt in the text. The narrator does not mince words in his disapproval of the perversion of journalistic standard and debasement of journalists in the performance of their duties. The media purposefully help politicians to pervert the truth and discredit their perceived opponents. For instance, when the Minister of finance presents "a complete plan" to address the country's "dangerous financial crisis" resulting from the "slum in the international coffee market" (2001: 3), "the Prime Minister said 'No' to the plan. He was not going to risk losing the election by cutting down the price paid to coffee planters at that critical moment" (2001: 3). Alternatively, in the spirit of unethical politics, he directs that the "National Bank should be instructed to print fifteen million pounds" (2001: 3 ).

Mindful of the dire consequences of such a directive to the national economy in the long term, "[t]wo-thirds of the Cabinet supported the Minister" (2001: 3). The next morning, however, the Prime Minister announces their dismissal in a broadcast to the nation. Characteristic of unscrupulous politicians in such circumstances, the Prime Minister discredits his former colleagues and causes public dissatisfaction form them. As the narrator puts it, "[h] e said the dismissed Ministers were conspirators and traitors who had teamed up with foreign saboteurs to destroy the new nation" (2001: 3). The media lap the contents of this broadcast and press the public destruction button against unfortunate patriotic citizens who rather mean well for their compatriots and their country. Thus [ $\mathrm{t}$ ] he newspapers and the radio carried the Prime Minister's version of the story" (2001: 3). Subsequently, the expected public reactions elicited through this politically and socially damaging broadcasting follow, as matter of cause. Knowing not the truth, $[\mathrm{w}] \mathrm{e}$ were very indignant. Our Students' Union met in emergency session and passed a vote of confidence in the leader and called for a detention law to deal with the miscreants." Besides, the whole country was behind the leader. Protest marches and demonstrations were staged up and down the land" (2001: 3). 
In all these, the media fail to do any critical analysis of the situation at hands. Rather, the media get along with the publication of highly subjective views of their political allies and twist the facts in pursuit of their selfish political interests. The terroristic stance of the media is further revealed in the Editorial published by the Daily Chronicle. According to the narrator, "the Daily Chronicle, an official organ of the POP, had pointed out in an editorial that the Miscreant Gang, as the dismissed ministers were now called, were all University people and highly educated professional men" (2001:4 - 5). This editorial exposes what this paper christens 'the spirit of intellectophobia' in the socio-cultural, economic and political setting in the narrative. This unfortunate development defies Plato's position on the significance of the role of philosopher-kings in the development of the Republic. Going by the infusions of this editorial, it is obvious that those who are still in Government, following the dismissal of the 'University people and highly educated professional men', lay no claim to any university degrees, and are not highly educated professional men.

The media, far from assuming their independent, unbiased and objective identity as the fourth estate of the realm so as to hold corrupt and unscrupulous politicians and citizens in check have turned themselves into destructive propaganda conduits for such people, to the detriment of the new nation in the narrative. The media are the driving force behind the 'intellecto-phobic' agenda in the text. Hence the Daily Chronicle's defamatory editorial piece describing the wrongfully expelled Ministers as "the Miscreant Gang" made up of "university people and highly educated professional men" (2001: 4).

The narrator's repugnance for the Daily Chronicle's pronounced destructive campaign against intellectuals and professionals in politics and public administration is heightened through a parenthetical statement as follows: "(I have preserved a cutting of that editorial.). (2001: 4). The choice of the verb 'preserved' in this parenthetical statement is also quite instructive. It reveals the narrator's determination to immortalize authentic historical record to serve as evidential exhibit for the justification of his denunciation of the unholy connivance between unscrupulous politicians and the media to conceal the truth and clamp down on those they consider as working against the selfish interest of self-defined members of the political ruling class in A Man of the People. They conspire to turn such people into public enemies, as it is in the case of the dismissed Minister of Finance and his colleagues. Ironically, they are rather portrayed as villains by the 'actual villains and nation-wreckers' in connivance with a perverted gangster media. Moreover, the narrator's attempt to reproduce the integral content of that editorial attests to his desire to be factual and accurate in his denunciation of media as an instrument or a conduit sociocultural, economic and political bastardization in the text. The media denounced as being a medium for character assassination, human rights violation and blackmail. The media aid unscrupulous and perverse politicians like Chief 
the Honourable M.A. Nanga, MP and his likes to manipulate unsuspecting citizens and expose them to perpetual exploitation. Media negative publications are put up to denigrate and discredit innocent citizens whose only crime is their fierce desire to effectively kick against corruption and help address the basic needs of the people. For instance, the Daily Chronicle editorial reads:

Let's now and for all time extract from our body-politic as a dentist extracts a stinking tooth all those decadent stooges versed in text-book economics and aping the white man's mannerisms and way of speaking. We are proud to be African. Our true leaders are not those intoxicated with their Oxford, Cambridge or Harvard degrees but those who speak the language of the people. Away with the damnable and expensive university education which only alienate an African from his rich and ancient culture and puts him above his people. (2001: 4)

The media's active involvement in driving far the 'intellecto-phobic' agenda is further denounced when the narrator re-echoes how other newspapers fuelled the hate-speech initiated by the Daily Chronicle. According to the narrator,

The cry was taken up on all sides. Other newspapers pointed out that even in Britain where the Miscreant Gang got its' 'so-called education' a man need not have an economist to be Chancellor of the Exchequer or a doctor to be Minister of Health. What mattered was loyalty to the party. (2001: 4)

Indeed, these publications enrage the people against the dismissed Minister of Finance and his colleagues.

That week his car had been destroyed by angry mobs and his house stoned. Another dismissed minister had been pulled out of his car, beaten insensible, and dragged along the road for fifty yards, then tied hand and foot, gagged and left by the roadside. He was still in the orthopaedic hospital when the house met. (2001: 4)

Elsewhere, the narrator brings to the fore corruption and blackmail in the media, as he narrates the story of the Editor of the Daily Matchet who comes to extort money from Chief Nanga to settle his rent.

I knew the Editor already from a visit he had paid the Minister a few days earlier. A greasy-looking man, he had at first seemed uneasy about my presence in the room and I had kept a sharp look 
out for the slightest hint from Chief Nanga to get up and leave them. [...] Our visitor took a very long time to come to the point, whatever it was. All I could gather was that he had access to something which he was holding back in Chief Nanga's interest. ...the Minister did not attach very great importance whatever it was; in fact he appeared to be sick and tired of the man but dare not say so. Meanwhile the journalist told us one story after another, a disgusting white foam appearing at the corners of his mouth. He drank two bottles of beer, smoked many cigarettes and then got a 'dash' of five pounds from the Minister after an account of his trouble with his landlord over arrears of rent. (2001: 60)

The Minister pours out his heart to the narrator over the exploitative role of the media following this visit:

You see what it means to be a minister' said Chief Nanga as soon as his visitor had left. [... If I I don't give him something now, tomorrow he will go and write rubbish about me. They say it is the freedom of the press. But to me it is nothing short of the freedom to crucify innocent men and assassinate their character. I don't know why our government is so afraid to deal with them. I don't say they should not criticize - after all no one is perfect except God - but they should criticize constructively... (2001: 60)

The minister's lamentations in the above lines over the media blackmail sums up the narrator's denunciation of how low the media has sunk in corruption and is unable to play a watchdog role in nation building.

\subsection{Conclusion}

Characters and events which serve as building materials for A Man of the People bear a great deal of resemblance with contemporary socio-political and economic characters and events in most African countries. In the light of this observation, we pause to ask the following rhetorical questions, "what lessons have we learnt from the plethora of literary works in our schools, colleges and universities over the many years that have shaped nation building in Africa? Is literature really seen as social discourse or a mere product of the fertile imagination of authors devoid of any serious consideration?" 
The significance of satirical denunciative discourse in the text lies in the conscious and successful effort of its narrator to expose the socio-cultural, economic and political corruption which is the hallmark of the emerging nation-state depicted in the narrative. Considering the nefarious impact of these evils on the development and stability of the nation-state, as divulged by the narrator through the satirical denunciative discourse in the narrative, useful lessons should be drawn by contemporary nation-states to guard them in their quest for sustainable socio-economic, political and human development to guarantee peace and security for all.

The combined effect of satirical linguistic denunciation tools and stylistic detours as examined in this paper is that it helps us identify the narrative in A Man of the People as a satirical discourse which reveals the dirty intricacies of African politics, names and shames corrupt characters in society while inciting critical minds to take up the mantle of responsibility to redeem the African continent from unscrupulous politicians such as Chief the Honourable M.A. Nanga, MP, and his likes. It equally calls for attitudinal and behavioural changes driven by core democratic values such as justice, equality, integrity and meritocracy, and the rejection of moral and political perversion inimical to sustainable human development and security in Africa. The phenomenon as studied further helps to project literary discourses such A Man of the People and many others, to be read beyond their aesthetic appreciation as vehicles for socio-cultural, economic and political engineering.

All in all, the study can conclude that satirical denunciative discourse in Achebe's narrative discourse, A Man of the People, combines irony, paradox, antithesis, colloquialism, anti-climax, violence, obscenity, vividness and exaggeration to bring to the fore the express need for socio-cultural, economic and political transformation and behavioural change to eschew corruption and ensure sustainable democratic governance. Contemporary socio-economic and political development and governance related challenges in many African countries and beyond show that Achebe's call for democratic behavioural change in a Nigerian setting, well over forty-nine years ago, remains relevant. 


\section{References}

Achebe, C., 2001. A Man of The People. London: Penguin Classics.

Armah, A. K., 1968. The Beautyful Ones Are Not Yet Born. London: African Writers Series.

Barber, R. J. \& Berdan, F., 1998. The Emperor's Mirror: Understanding Cultures Through Primary Sources. Arizona: University of Arizona Press. http://grammar.about.com/od/d/g/dysphemismtem.htm

Denunciation. Microsoft ${ }^{\circledR}$ Encarta ${ }^{\circledR}$ 2009. (C) 1993-2008 Microsoft Corporation. All rights reserved.

Djoleto, A., 1975. Money Galore. Heinemann : Essex.

Discourse Analysis. www.dictionary.com/browse/discourse-analysis [Accessed 15/04/2015]

Discourse Analysis. Microsoft ${ }^{\circledR}$ Encarta ${ }^{\circledR}$ 2009. ( $1993-2008$ Microsoft Corporation. All rights reserved.

Discourse. Microsoft ${ }^{\circledR}$ Encarta ${ }^{\circledR}$ 2009. ㄷ 1993-2008 Microsoft Corporation. All rights reserved.

Fitzpatrick, S. and Gellately, R., 1997. Introduction to the Practices of Denunciation in Modern European History. In Accusatory Practices: Denunciation in Modern European History, 1789-1989. Chicago.

Foucault, M., 1972. Archaeology of knowledge. New York: Pantheon.

Fowler, R., 1981. Literature as Social Discourse: The Practice of Linguistic Criticism. London: Batsford Academic and Educational Ltd.

Gellately, R., 2001. Denunciation as a Subject of Historical Research. Historical Social Research. Vol. 26. No. 2/3. 16 - 29.

Kourouma, A., 1970. The Suns of Independence. Heineman Educational Books Ltd.: London. African Writers Series 239, in Translation, Adrian Adams (1981).

van Dijk, T. A., 2001. Critical Discourse Analysis. In Deborah Schiffrin, D. et al. (Eds.). The Handbook of Discourse Analysis. (pp. 352-371). Oxford: Blackwell. 